\title{
PENGARUH METODE STRATAGEM MELALUI PEMBELAJARAN KOOPERATIF TERHADAP PEMAHAMAN KONSEP MATEMATIS SISWA KELAS VIII SMP NEGERI 20 PADANG
}

\author{
Alfi Yunita \\ Program Studi Pendidikan Matematika STKIP PGRI Sumatera Barat \\ Korespondensi: Jl. Gunung Pangilun Padang - Sumatera Barat
}

\begin{abstract}
The goal of this research was to know: "Was the students' understanding of mathematics concept who were taught by using 'Stratagem' Method through cooperative learning better than conventional Method." The research method was Quasi Experimental Research, Post-test Only Control Design. Data was collected from the test. From data data analysis, it was found that the students' understanding of mathematics concept who were taught by using 'Stratagem' Method through cooperative learning was better than conventional Method.
\end{abstract}

Kata kunci: metode stratagem, pembelajaran kooperatif, pemahaman konsep matematis

\section{PENDAHULUAN}

$\mathrm{M}$ atematika adalah ilmu dasar bagi dunia pendidikan karena matematika sangat mendukung untuk mempelajari ilmu-ilmu pengetahuan lainnya. Oleh sebab itu matematika merupakan pelajaran yang sangat penting diberikan di setiap jenjang pendidikan mulai dari tingkat sekolah dasar sampai perguruan tinggi. Adapun tujuan pembelajaran Matematika (Depdiknas, 2003: 1) sebagai berikut:

1. Melatih cara berfikir dan bernalar dalam menarik kesimpulan

2. Mengembangkan aktifitas kreatif yang melibatkan imajinasi dan penemuan dengan mengembangkan pemikiran divergen, rasa ingin tahu, membuat prediksi dan dugaan serta mencoba-coba.
3. Mengembangkan kemampuan menyampaikan informasi atau mengkomunikasikan gagasan.

Membantu siswa dalam menguasai matematika, perlu usaha maksimal agar tujuan pembelajaran matematika dapat tercapai seperti yang diharapkan. Salah satu usaha yang dapat dilakukan dalam pembelajaran matematika adalah guru seharusnya dapat memilih dan menggunakan metode pembelajaran yang tepat, sehingga siswa dapat memahami konsep matematika dengan baik.

Berdasarkan pengalaman dan pengamatan yang dilakukan pada saat mengajar matematika, ditemukan kondisi yang memperlihatkan kurangnya pemahaman konsep matematis siswa. Hal tersebut dapat dilihat dari kondisi yang jumpai pada saat observasi, yaitu ketika menyelesaikan persoalan matematika, sebagian siswa cenderung langsung memulai dengan formulasi-formu- 
lasi yang diperlukan tanpa mengikuti prosedur-prosedur yang seharusnya diikuti. Hal ini menunjukkan bahwa siswa masih belum memahami konsep matematis secara mendalam. Kondisi ini juga menunjukkan bahwa pemahaman siswa masih terfokus kepada contoh-contoh yang diberikan.

Mengatasi permasalahan di atas, dicoba menawarkan solusinya, yaitu dengan menggunakan metode stratagem melalui pembelajaran kooperatif dalam mengajar di kelas. Metode ini ditawarkan karena menurut (Munandir, 1991: 488) "Metode stratagem yaitu permainan belajar akademik". Belajar melalui permainan adalah aktivitas yang menyenangkan, ringan dan bersifat kompetitif seperti yang dikemukakan oleh (Romlah, 1989: 130) "Bermain merupakan cara belajar yang menyenangkan, karena dengan bermain bisa belajar sesuatu tanpa menyadarinya". Apa yang dipelajari itu disimpan dalam pikiran sehingga akan dipadukan menjadi suatu kesatuan dengan pengalaman lain yang kadang-kadang tanpa disadari.

Berdasarkan penjelasan di atas dapat kita gambarkan bahwa belajar dengan menggunakan metode stratagem melalui pembelajaran kooperatif pada hakikatnya adalah belajar sambil bermain dalam berkelompok dan berdiskusi dalam memecahkan masalah tanpa ada ketegangan dalam belajar, sehingga siswa termotivasi dalam belajar dan membantu siswa dalam meningkatkan pemahaman konsep matematis siswa.

Menunjang berjalannya proses pembelajaran kooperatif dengan baik diperlukan suatu panduan kegiatan, maka untuk itu guru perlu menyusun seperangkat lembaran kegiatan siswa (LKS) yang bisa memandu siswa dalam memahami konsep. Penggunaan LKS dalam model pembelajaran kooperatif ini diharapkan dapat membantu meningkatkan aktivitas siswa dalam proses pembelajaran karena LKS yang diberi- kan kepada siswa berupa suatu lembaran kerja yang harus dikerjakan oleh setiap siswa. Penemuan sendiri oleh siswa dalam menyelesaikan LKS akan menyebabkan siswa lebih banyak terlibat dalam proses pembelajaran. Dengan demikian diharapkan siswa akan terbantu dalam belajar matematika, seperti yang dikemukakan oleh (Hadi Sukanto, 1982: 1) "lembaran kerja siswa dapat mengaktifkan siswa, membantu siswa menemukan dan membantu siswa mengembangkan keterampilan proses".

Berdasarkan uraian di atas, dilakukan penelitian mengenai pengaruh penerapan metode stratagem melalui pembelajaran kooperatif terhadap pemahaman konsep matematis siswa kelas VIII SMP Negeri 20 Padang. Berpijak dari hal ini, permasalahan yang ingin dikaji dalam penulisan ini adalah apakah pemahaman konsep matematis siswa yang diajar dengan metode stratagem melalui pembelajaran kooperatif lebih baik dari pada siswa yang diajar dengan metode konvensional?

\section{LANDASAN TEORI}

\section{Pembelajaran Matematika}

Dalam belajar matematika terjadi suatu perubahan dalam individu yang belajar. (Herman, 1990: 7) menyatakan bahwa apabila proses belajar matematika itu baik, dapat diharapkan hasil belajar peserta didik akan baik pula. Dengan kata lain apabila proses belajar matematikanya baik maka subjek yang belajar akan memahami matematika dengan baik pula dan dia akan lebih mudah mempelajari matematika selanjutnya. Oleh karena itu untuk mengajarkan pelajaran matematika, guru harus mencari metode mengajar yang cocok untuk penyajian materi agar siswa mudah memahaminya. (Slameto, 1995: 64) mengatakan: "Metode mengajar adalah suatu cara atau jalan yang harus dilalui 
dalam mengajar". Metode mengajar guru yang kurang baik akan mempengaruhi belajar siswa yang tidak baik pula. Guru harus mampu menentukan metode mengajar serta alat bantu yang tepat yang sesuai dengan bahan yang disajikan juga sesuai dengan tujuan yang hendak dicapai sehingga materi mudah diterima siswa.

Berdasarkan kutipan di atas, dalam pembelajaran guru harus mampu memilih metode pembelajaran yang sesuai dengan materi yang akan dipelajari dan juga sesuai dengan tujuan pembelajaran. Ini berarti bahwa tidak mungkin guru hanya menggunakan satu metode saja dalam proses pembelajaran. Salah satu model pembelajaran yang dapat menggunakan metode bervariasi adalah model pembelajaran kooperatif.

\section{Pembelajaran Kooperatif}

Pembelajaran kooperatif merupakan metode pembelajaran kelompok. Siswa dalam pembelajaran ini diharapkan dapat bekerjasama dan saling membantu sesama anggota kelompoknya untuk mempelajari suatu materi pelajaran dan mengerjakan tugas-tugas yang diberikan oleh guru. (Anita, 2002: 12) menjelaskan bahwa sistem pengajaran yang memberikan kesempatan kepada anak didik untuk bekerjasama dengan sesama siswa dalam tugas-tugas yang terstruktur disebut sebagai sistem "pembelajaran gotong royong" atau cooperative learning". Selanjutnya (Anita, 2002: 6) juga menjelaskan bahwa dalam penerapan pembelajaran kooperatif dua atau lebih individu saling tergantung satu sama lain untuk mencapai satu penghargaan bersama. Mereka akan berbagi penghargaan tersebut seandainya mereka berhasil sebagai kelompok. Ini berarti bahwa anggota kelompok akan saling bekerjasama dan saling membantu untuk mempelajari suatu materi, melengkapi tugas-tugas serta menyelesaikan suatu masalah. Keberhasilan seseorang adalah keberhasilan kelompok.

Ciri-ciri pembelajaran kooperatif menurut (Muslim Ibrahim, 2001: 6) sebagai berikut: 1) Siswa bekerja dalam kelompok secara kooperatif untuk menuntaskan materi pelajaran, 2) Kelompok dibentuk dari siswa yang berkemampuan tinggi, sedang dan rendah, 3) Bilamana mungkin, anggota kelompok berasal dari ras, budaya, suku, jenis kelamin berbeda-beda, 4) Penghargaan lebih berorientasi kelompok ketimbang individu.

Selanjutnya, menurut (Muslim Ibrahim, 2001: 10) terdapat 6 langkah utama atau tahapan di dalam pembelajaran kooperatif yang terlihat dalam tabel berikut:

\begin{tabular}{ll}
\hline \multicolumn{1}{c}{ Fase } & \multicolumn{1}{c}{ Tingkah Laku Guru } \\
\hline $\begin{array}{l}\text { Fase-1 } \\
\text { memyampaikan tujuan dan }\end{array}$ & $\begin{array}{l}\text { Guru menyampaikan semua tujuan pelajaran } \\
\text { yang ingin dicapai pada pelajaran tersebut dan } \\
\text { memotivasi siswa belajar. }\end{array}$ \\
$\begin{array}{l}\text { Fase-2 } \\
\text { Menyampaikan informasi }\end{array}$ & $\begin{array}{l}\text { Guru menyampaikan informasi kepada siswa } \\
\text { dengan jalan demonstrasi atau lewat bahan } \\
\text { bacaan. }\end{array}$ \\
$\begin{array}{l}\text { Fase-3 } \\
\begin{array}{l}\text { Mengorganisasikan siswa } \\
\text { ke dalam kelompok- } \\
\text { kelompok belajar }\end{array}\end{array}$ & $\begin{array}{l}\text { Guru menjelaskan kepada siswa bagaimana } \\
\text { caranya membentuk kelompok belajar dan } \\
\text { membantu setiap kelompok agar melakukan } \\
\text { transisi secara efisien. }\end{array}$ \\
\hline
\end{tabular}




\begin{abstract}
Fase-4
Membimbing kelompok bekerja dan belajar

Fase-5

Evaluasi

Fase-6

Memberikan penghargaan

Berdasarkan kutipan di atas terlihat bahwa peranan guru dalam pembelajaran kooperatif sangat kompleks. Guru sebagai facilitator dan reinforcer dalam memberdayakan kerja kelompok siswa. Guru harus bisa memotivasi siswa untuk aktif dan berpartisipasi dalam kegiatan
\end{abstract}

Guru membimbing kelompok-kelompok belajar pada saat mereka mengerjakan tugas mereka.

Guru mengevaluasi hasil belajar tentang materi yang telah dipelajari atau masing-masing kelompok mempresentasikan hasil karyanya.

Guru mencari cara untuk menghargai baik umpan maupun hasil belajar individu dan kelompok. belajar.

\section{Metode Stratagem}

Metode stratagem merupakan salah satu bentuk permainan akademik yang dikembangkan oleh (Munandir, 1991: 488). Metode permainan ini mempunyai batas waktu dan aturan-aturan tertentu, dimana siswa dibagi menjadi beberapa kelompok yang saling berkompetisi untuk mencapai tujuan tertentu. Jumlah pemainnya terbatas dan lama permainannya juga terbatas. Permainan ini cocok dipakai untuk memotivasi siswa dalam belajar, terutama bila bahan pelajaran yang dipelajarinya kurang menarik. Permainan ini dikembangkan dengan maksud mengurangi tekanan karena belajar dalam menghadapi ujian maupun tidak dan untuk meningkatkan usaha siswa dalam mengerjakan soal-soal pelajaran sehingga dapat meningkatkan hasil belajar peserta.

(Munandir, 1991: 488) menjelaskan bahwa cara belajar melalui permainan stratagem dalam pembelajaran kooperatif yaitu:

1. Permainan ini merupakan kegiatan belajar kooperatif yang terdiri dari 2
- 5 orang dimana mereka merupakan bankir dan juga pemain.

2. Menjawab pertanyaan secara bergiliran berdasarkan kartu-kartu soal.

3. Pemberian skor awal pada tiap kelompok.

4. Pemberian skor dalam setiap pertanyaan.

5. Setiap pertanyaan dijawab oleh kelompok selama 3 - 5 menit.

Pada permainan Stratagem ini yang ditetapkan sebagai bankir adalah guru dan sebagai pemain adalah siswa-siswa yang dibagi menjadi beberapa kelompok. Kartu-kartu yang digunakan adalah berupa kartu pertanyaan dan kartu jawaban yang berukuran $5 \times 7,50 \mathrm{~cm}$ dan pemberian skor pada tiap pertanyaan dibuat berdasarkan tingkat kesulitannya dan berdasarkan 6 langkah utama atau tahapan. Di dalam pembelajaran kooperatif dinyatakan bahwa guru menyampaikan informasi kepada siswa melalui demonstrasi atau lewat bahan bacaan, maka ditetapkan di dalam pembelajaran kooperatif ini menggunakan bacaan yang berupa Lembar Kerja Siswa (LKS).

\section{Metode Konvensional}

Metode konvensional adalah metode yang umum dipakai dalam pelaksanaan pembelajaran di kelas. Metode konvensional identik dengan metode pembelajaran dimana guru menjadi pusat dari kegiatan pembelajaran. Metode 
tersebut dikenal sebagai metode ceramah dan masih tetap digunakan dalam strategi belajar-mengajar. Metode ini paling tua, paling banyak dan paling sering dipakai dalam berbagai kesempatan. Di tengah-tengah perkembangan teknologi komunikasi sekarang ini, metode ini masih tetap bertahan.

Jika dicermati, dalam penerapan metode konvensional, guru menjadi pusat dari kegiatan pembelajaran dan mempunyai keunggulan antara lain hemat dalam penggunaan waktu dan alat, organisasi kelas sederhana, mampu membangkitkan minat dan antusias siswa apabila sesuatu yang dilihat, didengar bisa menarik perhatian siswa. Sedangkan kelemahan metode ini antara lain guru sukar mengetahui sampai dimana muridmurid telah mengerti pembicaraannya, murid sering memberi pengertian lain dari hal yang dimaksud guru.

\section{Pemahaman Konsep Matematis}

Pemahaman konsep matematis siswa dalam belajar matematika adalah salah satu tujuan penting dalam pembelajaran, memberikan pengertian bahwa materi-materi yang diajarkan kepada siswa bukan sebagai hafalan tetapi lebih jauh lagi. Pemahaman konsep matematik juga merupakan salah satu tujuan dari setiap materi yang disampaikan oleh guru, sebab guru merupakan pembimbing siswa untuk memahami konsep yang diharapkan. Pendidikan yang baik adalah usaha yang berhasil membawa siswa kepada tujuan yang ingin dicapai yaitu agar bahan yang disampaikan dipahami sepenuhnya oleh siswa.

Pemahaman merupakan terjemahan dari istilah understanding yang diartikan sebagai penyerapan arti suatu materi yang dipelajari. Untuk memahami suatu objek secara mendalam seseorang harus mengetahui: "(1) objek itu sendiri, (2) relasinya dengan objek lain yang sejenis, (3) relasinya dengan objek lain yang tidak sejenis, (4) relasi-dual dengan objek lainnya yang sejenis dan (5) relasi dengan objek dalam teori lainnya" (Utari, 1987: 89).

Pemahaman konsep matematis penting bagi siswa untuk belajar matematika secara bermakna, tentunya para guru mengharapkan pemahaman yang dicapai siswa tidak terbatas pada pemahaman yang bersifat dapat menghubungkan. Pemahaman terhadap konsep merupakan bagian yang sangat penting dalam proses belajar dan memecahkan masalah, baik di dalam proses belajar itu sendiri maupun di dalam kehidupan nyata. Kemampuan memahami konsep menjadi landasan untuk berpikir dalam menyelesaikan persoalan. (Ratna Wilis, 1989: 64) menyatakan: "belajar konsep merupakan hasil utama pendidikan". Konsep merupakan pilar pembangun berpikir dan juga merupakan dasar bagi proses mental yang lebih tinggi untuk merumuskan prinsip dan generalisasi.

Menurut (John, 2008: 5) indikator pemahaman konsep matematis yaitu: 1) Mengenal penguasaan dan bukti sebagai aspek yang mendasar dalam matematika, 2) Membuat dan menyelidiki dugaandugaan matematika, 3) Mengembangkan dan mengevaluasi argumen dan bukti matematis, 4) Memilih dan menggunakan berbagai macam penguasaan.

Sementara itu, menurut (Ansyar dan Sembiring R.K, 2001: 16) ada beberapa tingkat penguasaan konsep dalam matematika, yaitu: 1) Mengucapkan konsep dengan tepat dan benar; 2) Menjelaskan konsep dengan kalimat dan kata-kata biasa; 3) Mengidentifikasi keberlakuan dan ketidakberlakuan konsep; 
4) Menginterpretasikan suatu konsep; 5) Menerapkan konsep dengan benar; 6) Kemampuan berkomunikasi mengenai matematika dan mengkomunikasikan matematika.

Berdasarkan penjelasan di atas dapat disimpulkan bahwa siswa memiliki pemahaman konsep matematis jika siswa mampu melakukan hal-hal berikut: (1) menyebutkan dan menjelaskan konsep secara benar, (2) menerapkan konsep secara tepat, dan (3) memberikan contoh dari suatu konsep dengan tepat.

Dalam penelitian ini, indikator pemahaman konsep matematis siswa yang diukur adalah menyebutkan dan menjelaskan konsep dengan benar, menerapkan konsep secara benar dan memberikan contoh dari suatu konsep secara tepat.

\section{METODOLOGI PENELITIAN}

\section{Jenis dan Alur Penelitian}

Penelitian ini menggunakan pendekatan kuantitatif dalam bentuk Quasi Experiment Design. Rancangan penelitian yang digunakan adalah PosttestOnly Control Design yang terdiri dari dua kelompok. Variabel pada penelitian ini terdiri dari (a) variabel bebas yaitu metode pembelajaran, (b) variabel terikat yaitu pemahaman konsep matematis.

\section{Populasi dan Sampel}

Populasi dalam penelitian ini adalah siswa kelas VIII tahun pelajaran 2010/2011 di SMP Negeri 20 Padang yang terdiri dari 8 kelas dengan jumlah siswa seperti terlihat pada Tabel 1 berikut ini.

Tabel 1. Jumlah siswa kelas VIII SMP Negeri 20 Padang

\begin{tabular}{ccc}
\hline No & Kelas & Jumlah Siswa \\
\hline 1. & VIII.1 & 39 \\
\hline 2. & VIII.2 & 37 \\
\hline 3. & VIII.3 & 34 \\
\hline 4. & VIII.4 & 40 \\
\hline 5. & VIII.5 & 33 \\
\hline 6. & VIII.6 & 36 \\
\hline 7. & VIII.7 & 35 \\
\hline 8. & VIII.8 & 39 \\
\hline
\end{tabular}

Teknik pengambilan sampel yang digunakan dalam penelitian ini adalah Purposive Sampling. Terpilihnya sebagai sampel adalah kelas VIII.1 dan kelas VIII.8 dengan pertimbangan guru yang mengajar pada kedua kelas ini adalah sama dan memberikan peluang kepada peneliti untuk melakukan penelitian di SMP Negeri 20 Padang. Dari hasil perhitungan dimana kedua kelas tersebut tidak terdapat perbedaan maka dipilihlah kelas VIII.1 sebagai kelas eksperimen dan kelas VIII.8 sebagai kelas kontrol setelah dilakukan uji kesamaan rata-rata.

\section{Definisi Operasional}

Menggambarkan ruang lingkup yang menjadi batasan penelitian maka dikemukakan definisi operasional sebagai berikut:

1. Metode Stratagem merupakan salah satu bentuk permainan akademik yang mempunyai batas waktu dan aturan-aturan tertentu, dimana siswa dibagi menjadi beberapa kelompok yang saling berkompetisi untuk menyelesaikan soal yang dibagikan berupa kartu soal, dan lamanya permainan juga ditentukan. Sedangkan Model Pembelajaran kooperatif adalah proses belajar mengajar yang 
dijalankan dengan cara mengelompokkan siswa ke dalam kelompok-kelompok kecil untuk memecahkan masalah dan tugas-tugas pembelajaran.

2. Metode konvensional merupakan metode pembelajaran yang berpola teacher-centered atau berpusat pada guru. Proses pembelajaran didominasi oleh guru dengan metode ceramah.

3. Hasil belajar kognitif merupakan skor tes yang diperoleh dalam mengukur kemampuan matematika siswa yang terdiri dari kemampuan pemahaman konsep, kemampuan komunikasi matematika dan kemampuan pemecahan masalah. Tes diberikan berbentuk tes essay.

4. Indikator pemahaman konsep pada penelitian ini adalah sebagai berikut:

a) Menyebutkan dan menjelaskan konsep dengan benar, b) Menerapkan konsep secara benar, c) Memberikan contoh dari suatu konsep secara tepat.

\section{Pelaksanaan Pembelajaran Meng- gunakan Metode Stragem}

Permainan stratagem di kelas eksperimen dilakukan dengan cara sebagai berikut:

1. Sepasang kelompok yang berkompetisi berhadap-hadapan.

2. Guru membagikan kartu soal dan jawaban kepada kelompok yang berbeda dalam pasangan permainan tersebut. Kartu jawaban diberikan dalam keadaan tertelungkup dan untuk menjaga kerahasiaan jawaban maka kartu jawaban disegel atau diklep.

3. Salah seorang anggota kelompok yang mendapat soal membuka soal dan membacakannya, kemudian tiap pasangan tersebut membahas soal. Tiap pasangan boleh mendapatkan bantuan dari teman sekelompoknya untuk menyelesaikan soal yang diberikan dan setiap siswa bertanggung jawab menyelesaikan soal tersebut bersama kelompoknya.

4. Jika kelompok penjawab (pemegang kartu soal) selesai menjawab soal sesuai dengan waktu yang telah ditentukan, maka kelompok pasangannya (pemegang kartu jawaban) membuka kartu jawaban dan menyesuaikannya dengan jawaban yang ada.

5. Jika kelompok penjawab menjawab dengan benar maka bankir mencatat penambahan skor kelompok yang diperoleh sesuai dengan skor soal, jika salah skor dikurangi sesuai dengan skor soal.

6. Jika kelompok penjawab menjawab salah dalam waktu tertentu tidak dapat menjawab, maka kelompok pasangannya berhak menjawab soal, jika jawabannya benar maka memperoleh skor setengah dari skor soal, jika salah skornya tidak dikurangi.

7. Selanjutnya permainan diulangi, guru membagikan kartu soal kepada kelompok yang tadinya mendapat kartu jawaban, demikian sebaliknya. Permainan dilakukan kembali sesuai dengan peraturan yang berlaku.

8. Siswa bersama-sama dengan panduan guru menyimpulkan materi yang dipelajari dan guru memberikan PR, dan meminta siswa untuk langsung duduk pada kelompok yang sama pada pertemuan selanjutnya.

9. Pada kelas kontrol dilakukan pembelajaran dengan metode konvensional.

Berikut dijelaskan proses pelaksanaan pembelajaran pada kelas kontrol, yaitu:

1. Siswa duduk secara klasikal.

2. Guru menyampaikan tujuan pembelajaran.

3. Guru menjelaskan materi, kemudian diberi contoh soal.

4. Guru meminta siswa untuk bertanya mengenai bagian yang tidak dimengerti, kemudian siswa diminta untuk menyelesaikan soal-soal yang ada 
pada buku sumber dan dibahas bersama-sama pada akhir pembelajaran.

5. Guru membimbing siswa membuat kesimpulan dan memberikan latihan untuk dikerjakan di rumah (PR).

\section{Instrumen Penelitian}

Data dalam penelitian ini diperoleh dengan menggunakan instrumen penelitian berupa tes pemahaman konsep matematis siswa yang berbentuk essay. Tes pemahaman konsep yang digunakan dalam penelitian ini bertujuan untuk memperoleh data kuantitatif berupa skor pemahaman konsep matematis siswa setelah mengikuti pembelajaran. Tes pemahaman konsep matematis ini disusun berdasarkan indikator pembelajaran yang dituangkan dalam kisi-kisi tes. Tes pemahaman konsep matematis ini disusun dalam bentuk esai, yang diukur melalui 2 butir soal yaitu soal nomor 1a, dan 1b. Penyusunan dan pemberian skor butir soal tes pemahaman konsep dapat dilihat pada Tabel 2.

Tabel 2. Kriteria Penilaian Pemahaman Konsep Matematika

\begin{tabular}{clll}
\hline Skor & $\begin{array}{c}\text { Menuliskan dan } \\
\text { menjelaskan }\end{array}$ & $\begin{array}{c}\text { Menerapkan } \\
\text { konsep }\end{array}$ & $\begin{array}{c}\text { Memberikan } \\
\text { contoh dari konsep }\end{array}$ \\
\hline 0 & $\begin{array}{l}\text { Tidak ada / salah } \\
\text { menyebutkan dan } \\
\text { memahami }\end{array}$ & $\begin{array}{l}\text { Salah memahami } \\
\text { dan menerapkan } \\
\text { konsep }\end{array}$ & $\begin{array}{l}\text { Tidak / salah } \\
\text { memberikan contoh }\end{array}$ \\
\hline 1 & $\begin{array}{l}\text { Memahami konsep } \\
\text { kurang lengkap }\end{array}$ & $\begin{array}{l}\text { Menerapkannya } \\
\text { kurang tepat }\end{array}$ & $\begin{array}{l}\text { Memberikan contoh } \\
\text { kurang lengkap }\end{array}$ \\
\hline 2 & Memahami konsep & Menerapkannya & $\begin{array}{l}\text { Memberikan contoh } \\
\text { hampir lengkap }\end{array}$ \\
\hline 3 & hampir lengkap & hemahamir tepat & hansep \\
& Mengan lengkap & $\begin{array}{l}\text { Menerapkannya } \\
\text { secara tepat }\end{array}$ & $\begin{array}{l}\text { Memberikan contoh } \\
\text { dengan tepat }\end{array}$ \\
\hline
\end{tabular}

Dari Tabel 2, ada tiga aspek yang diukur untuk mengetahui pemahaman konsep siswa, yaitu menyebutkan dan menjelaskan konsep, menerapkan konsep dan memberikan contoh dari suatu konsep. Karena jawaban yang diberikan siswa tidak seragam, maka pada setiap aspek yang diukur diberikan skor 0 sampai 3, dengan tujuan yaitu, agar setiap jawaban siswa mendapatkan penilaian yang sesuai dengan jawaban yang diberikan.

\section{Teknik Analisis Data}

Analisis data dilakukan untuk menguji hipotesis yang telah dirumuskan. Untuk menentukan uji statistik yang digunakan, terlebih dahulu ditentukan normalitas data dan homogenitas variansi. Uji normalitas bertujuan untuk mengetahui apakah masing-masing kelompok data berdistribusi normal atau tidak. Uji homogenitas variansi bertujuan untuk mengetahui apakah variansi kedua kelompok sampel sama atau berbeda.

Selanjutnya dilakukan pengujian hipotesis. Uji hipotesis dilakukan setelah dilakukan uji normalitas dan uji homogenitas terhadap kelas sampel. Untuk kedua kelompok data yang berdistribusi normal dan variansi homogen maka rumus yang digunakan adalah:

$$
\begin{gathered}
\mathrm{t}=\frac{\left|\bar{x}_{e}-\bar{x}_{k}\right|}{\sqrt{s_{x-y}^{2}\left(\frac{1}{n_{x}}+\frac{1}{n_{y}}\right)}}, \\
\text { dengan df }=n_{x}+n_{y}-2 \text {, dan } \\
\frac{\mathrm{s}_{x-y}^{2}}{s_{x}^{2}\left(n_{x}-1\right)+s_{y}^{2}\left(n_{y}-1\right)} \\
n_{x}+n_{y}-2
\end{gathered}
$$


Keterangan:

$\bar{x}_{1}=$ rata-rata kelas eksperimen

$\bar{x}_{2}=$ rata-rata kelas kontrol

$S_{1}^{2}=$ simpangan baku kelas eksperimen

$S_{2}^{2}=$ simpangan baku kelas kontrol

$n_{1}=$ jumlah siswa kelas eksperimen

$n_{2}=$ jumlah siswa kelas kontrol

Kriteria pengujiannya adalah tolah $\mathrm{H}_{0} \quad$ jika $\quad \mathrm{t}_{\text {hitung }}>t_{(1-\alpha)}$ dengan $\mathrm{df}=\left(\mathrm{n}_{1}-\mathrm{n}_{2}-2\right)$ selain itu $\mathrm{H}_{0}$ diterima (Sudjana, 1992:239).

\section{HASIL PENELITIAN}

\section{Deskripsi Data}

Setelah dilakukan pengolahan data hasil tes kemampuan pemahaman konsep matematika pada kedua kelompok, diperoleh skor tertinggi, skor terendah, skor rata-rata, dan standar deviasi yang disajikan pada diagram batang di bawah ini.

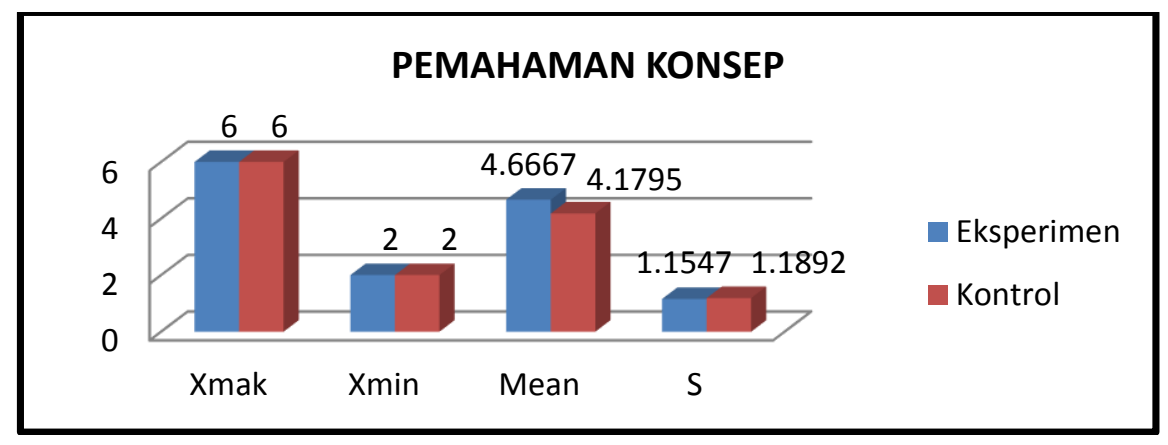

Gambar 1. Diagram Batang Nilai Tertinggi, Terendah, Rata-rata dan Simpangan Baku untuk Pemahaman Konsep

Pada Gambar 1 terlihat bahwa rata-rata pemahaman konsep siswa yang menggunakan metode stratagem melalui pembelajaran kooperatif lebih tinggi daripada menggunakan metode konvensional. Berdasarkan data simpangan baku maka skor pemahaman konsep siswa yang menggunakan metode konvensional menyebar dibandingkan dengan yang menggunakan metode stratagem melalui pembelajaran kooperatif. Hal ini menunjukkan, bahwa sebaran skor pemahaman konsep matematika tersebut pada kelas eksperimen lebih memusat ke rata-rata dibandingkan kelas kontrol.

\section{Pengujian Persyaratan Analisis}

a. Uji Normalitas

Hasil perhitungan uji normalitas untuk tiap kelompok data dapat dilihat pada Tabel 3.

Tabel 3. Hasil Uji Normalitas untuk setiap kelompok

\begin{tabular}{clccl}
\hline Aspek & Perlakuan & Lhitung & Ltabel & Normalitas \\
\hline \multirow{2}{*}{ Pemahaman Konsep } & Eksperimen & 0,1300 & 0,141 & Normal \\
\cline { 2 - 5 } & Kontrol & 0,1241 & 0,141 & Normal \\
\hline
\end{tabular}

Berdasarkan hasil ujian normalitas pada Tabel 3 diperoleh nilai $\mathrm{L}_{\text {tabel }}>\mathrm{L}_{\text {hitung sehingga dapat disimpulkan }}$ bahwa pemahaman konsep matematis siswa berdistribusi normal. b. Uji Homogenitas Variansi

Hasil perhitungan uji homogenitas variansi untuk setiap kelompok dapat dilihat pada Tabel 4. 
Tabel 4. Hasil Uji Homogenitas Variansi

\begin{tabular}{lccc}
\hline Aspek & $\boldsymbol{F}_{\text {hitung }}$ & $\boldsymbol{F}_{\text {tabel }}$ & Homogenitas \\
\hline $\begin{array}{l}\text { Pemahaman Konsep } \\
\text { Matematis }\end{array}$ & 1,06 & 1,72 & Homogen \\
\hline
\end{tabular}

Berdasarkan hasil uji homogenitas variansi pada Tabel 4 tersebut, diperoleh variansi data untuk pemahaman konsep matematis antara kelompok eksperimen dan kontrol, menunjukkan bahwa $F_{\text {hitung }}<$ $F_{\text {tabel }}$ pada $\alpha=0,05$. Hal ini berarti variansi kedua kelompok adalah homogen.

\section{c. Pengujian Hipotesis}

Setelah dilakukan perhitungan perbedaan rata-rata menggunakan uji $t$ diperoleh $t_{\text {hitung }}=1,83$, sedangkan $t_{\text {tabel }}$ untuk $\alpha=0,05$ adalah 1,67. Karena $t_{\text {hitung }}>\mathrm{t}_{\text {tabel }}$, maka $\mathrm{H}_{0}$ ditolak. Dapat disimpulkan bahwa pemahaman konsep matematika siswa yang diajar dengan metode stratagem melalui pembelajaran kooperatif lebih baik daripada pemahaman konsep matematika siswa yang diajar dengan metode konvensional.

\section{PEMBAHASAN}

Berdasarkan uji statistik terhadap perbedaan rata-rata memberikan hasil yang signifikan. Dengan kata lain, pemahaman konsep matematis siswa yang diajar dengan metode stratagem melalui pembelajaran kooperatif berbeda dengan siswa yang diajar dengan metode konvensional. Hal ini diduga karena pembelajaran yang dilaksanakan dapat memotivasi siswa dalam belajar.

Pada pembelajaran dengan menggunakan metode stratagem melalui pembelajaran kooperatif suasana belajar berbeda dengan yang biasanya. Mereka dapat belajar sambil bermain, lebih menyenangkan dan kondisi belajarpun lebih kondusif, karena dilihat dari usia siswa kelas VIII adalah usia dimana mereka cenderung untuk bermain.
Dengan metode stratagem memfasilitasi mereka untuk dapat belajar sambil bermain. Hal ini sesuai dengan yang dikatakan Tatik (1989: 130): "permainan merupakan suatu aktifitas yang menyenangkan, ringan dan bersifat kompetitif, atau kedua-duanya". Siswa lebih termotivasi untuk menyelesaikan soal-soal yang diberikan dalam bentuk kartu soal. Disamping mereka terpacu untuk menyelesaikan soal lebih cepat mereka juga dituntut untuk saling berbagi dengan anggota lain dalam kelompoknya. Hal ini sesuai dengan pendapat Anita Lie (2002: 6) yang menyatakan dalam pembelajaran kooperatif dua atau lebih individu saling bergantungan satu sama lain untuk mencapai satu penghargaan bersama. Dengan demikian pemahaman konsep akan lebih bermakna bagi siswa karena mereka akan berbagi penghargaan tersebut seandainya mereka berhasil dalam menyelesaikan soal yang diberikan dalam kelompok.

Berdasarkan pengamatan selama proses pembelajaran dengan menggunakan metode stratagem melalui pembelajaran kooperatif terlihat bahwa siswa mampu menulis konsep dengan tepat dan benar serta mampu menjelaskan konsep dengan bahasa mereka sendiri. Pembelajaran ini memberikan kesempatan yang lebih banyak kepada siswa untuk bisa menemukan sendiri ataupun berkelompok penyelesaian setiap permasalahan dan konsep. Keunggulan metode stratagem melalui pembelajaran kooperatif adalah pengetahuan dikonstruksi sendiri oleh siswa dari masalah-masalah yang diberikan guru.

Sementara itu, pada kelas control yang menggunakan metode konvensional, setelah menyampaikan materi, siswa diminta mengerjakan soal-soal 
latihan pemahaman konsep yang ada pada buku paket. Siswa cenderung tidak mau mengerjakan, mereka lebih memilih diam atau hanya menyalin pekerjaan temannya. Mereka mengerjakan soal tersebut sendiri-sendiri. Tetapi pada kelas eksperimen sewaktu siswa diminta mengerjakan soal-soal yang dikompetisikan, siswa berusaha mengerjakannya dengan cepat dan benar. Mereka termotivasi untuk mengerjakan soal karena menginginkan skor yang lebih tinggi dari kelompok lain. Siswa yang sudah selesai mengerjakan latihan dan membantu teman kelompoknya yang belum selesai mengerjakannya. Hal ini sesuai dengan teori Nur Asma (2008: 2) yang menyatakan bahwa "belajar kooperatif dapat membuat siswa bekerja sama dalam belajar kelompok dan sekaligus masingmasing bertanggung jawab pada aktivitas belajar anggota kelompoknya, sehingga seluruh anggota kelompok dapat menguasai materi pelajaran dengan baik".

\section{PENUTUP}

\section{Kesimpulan}

Penelitian ini merupakan penelitian yang membandingkan penggunaan dua metode pembelajaran, yaitu metode stratagem melalui pembelajaran kooperatif dan metode konvensional. Berdasarkan analisa data yang telah dikemukakan, diperoleh kesimpulan bahwa pemahaman konsep matematis siswa yang diajar dengan metode stratagem melalui pembelajaran kooperatif lebih baik daripada pemahaman konsep matematis siswa yang diajar dengan metode konvensional.
Berdasarkan hasil analisis data dapat disimpulkan bahwa penggunaan metode stratagem melalui pembelajaran kooperatif pada mata pelajaran matematika pokok bahasan teorema Pythagoras di SMP Negeri 20 Padang ternyata cukup efektif untuk meningkatkan hasil belajar matematika siswa pada pemahaman konsep matematis. Keuntungan menggunakan metode stratagem melalui pembelajaran kooperatif adalah materi pelajaran dikaitkan dengan suatu permainan dimana siswa bersaing dalam suatu kompetisi untuk mendapatkan suatu penghargaaan dan dalam pembelajaran kooperatif adanya saling ketergantungan positif, saling membantu, saling memberikan motivasi sehingga ada interaksi positif, sedangkan peran guru sebagai bankir dalam suatu permainan dan memberikan arahan pada siswa.

\section{Saran}

Berdasarkan kesimpulan di atas, maka peneliti mengemukakan beberapa saran antara lain:

1. Bagi guru matematika khususnya dan guru mata pelajaran lain umumnya dapat menggunakan metode stratagem melalui pembelajaran kooperatif sebagai alternatif untuk meningkatkan aktifitas belajar siswa dan hasil belajar siswa.

2. Kepada peneliti lanjutan yang ingin melakukan penelitian serupa dapat mencobakan pada tempat dan materi yang berbeda dan mengontrol variabel-variabel lain yang ikut mempengaruhi kemampuan matematika siswa serta menyertakan angket aktifitas siswa untuk melihat aktivitas siswa selama penerapan metode pembelajaran ini. 


\section{DAFTAR RUJUKAN}

Anita Lie. 2002. Cooperative Learning. Jakarta: Grasindo.

Depdiknas. 2003. Penyusunan Butir Soal dan Instrumen Penilaian. Jakarta: Dikdasmen.

Herman Hudoyo. 1990. Belajar Mengajar Matematika. Jakarta: Dirjen Dikti P2LPT

Munandir. 1991. Belajar dan Membelajarkan. Jakarta: Rajawali Pres.
Muslim Ibrahim, dkk. 2001. Pembelajaran Kooperatif. Surabaya: University Press.

Slameto. 1995. Belajar dan Faktorfaktor yang Mempengaruhinya. Jakarta: Bumi Aksara

Suherman, E dkk. 2003. Strategi Pembelajaran Matematika Kontemporer. JICA. UPI Bandung.

Tatiek Romlah. 1989. Teori dan Praktek Bimbingan Kelompok. Jakarta: Dikti LP3. 